of specific minerals. The first part has an oversimplified but not readily comprehended approach to electronic structure, followed by three very useful chapters entitled Conduction Mechanism, Other Electronic Properties and Heterogeneity and the Semiconductor Electrolyte Interface. All provide an extremely useful tex for workers and teachers of minera chemistry, flotation and hydrometallurgical chemistry.

The remaining sections describe the occurrences, the electronic and magnetic properties and the non-stoichiometry of various minerals including elements, sulphides, sulpharsenides and oxides. This is a useful source of data with many references but its utility would have been improved if the author had not taken a deliberate decision to employ units 'common in the literature' rather than convert to a consistent system such as the S.l. Apart from confusion to workers in the different fields many present-day students will not be familiar with c.g.s. units, especially for example e.m.u./g.

The type-setting is clear and legible despite being chosen for economic production in this age of high costs. The figures are clear and the tables concise; nevertheless a more uniform way of presentation of data would have been helpful. There seem to be a few obvious errors although of course numerical data needs checking against the original references. One obvious error is the suggestion on p. 7 that flotation agents are aqueous solutions of hydrocarbon.

The book will provide both a useful source of reference material on mineral properties as well as a useful text at postgraduate level for geochemists, hydrometallurgists and mineral processors, and perhaps at undergraduate finals level for chemistry and physics students interested in the solid state.

N.M. RICE

\section{Department of Mining}

and Mineral Sciences

University of Leeds

Leeds LS2 9JT

West Yorkshire

England

Diffraction physics. By John $M$ Cowley. Pp. xii +410 . Amsterdam: North Holland, 1975. Price Dfl 135.00 , U.S. \$56.25.

The publication of this book is an important event in the world of optics and microscopy. The author has made many fundamental contributions to the theory and practice of electron microscopy and electron diffraction, and when such a person decides to put his thoughts together in a systematic way in a textbook. one looks forward to a work that should be outstanding.

With this book one is not disappointed. The author has surveyed his field in masterly fashion; he discusses diffraction and image formation with light, $X$ rays, neutrons and electrons, but, having laid down the general principles of these subjects, he has wisely decided to concentrate mainly on the last. He deals with kinematic and dynamic theories, diffraction by imperfect structures, diffuse scattering, the study of defects, and orderdisorder phenomena, but subjects such as crystal-structure determination - on which many textbooks already exist - he dismisses very briefly indeed.

I am pleased to see that the author has adopted the approach that I have advocated over many years - introducing diffraction through the concept of the Fourier transform; this may sound complicated to those who have been brought up on Laue's equations and Bragg's law, but it does ultimately make the subject of diffraction more logical and self-consistent.

One subject of topical importance, to which the author has made considerable contributions, is given some prominence in the book - 'imaging of thin crystals' or what is often incorrectly called 'lattice imaging'. If a crystal of thickness about $100 \AA$ is viewed in a good electron microscope, an image closely resembling the structure found by $X$-ray diffraction can be seen. Since the aim of electron microscopists has always been to exploit the ultimate resolution of their instrument by producing images of individual atoms, it looks as though their ambition is now about to be fulfilled.

I have, however, some doubts. Electrons interact with crystals; they are not just scattered by them. It would not therefore be expected that they should give the same image as $X$-rays. Electron microscopes suffer from extreme spherical aberration, which means that the relative phases of the diffracted beams are affected - again producing a different image. Finally, the best image is produced with an 'underfocusing' of about $900 \AA$, which I find rather puzzling. The unit cell must be correct since it is based merely on the relative positions of the orders of diffraction; but how does one know that the fine detail really represents atoms? I shall be convinced only when the instrument produces new information.
The book is well produced, although, presumably for economy, the lines of print are not 'justified'. The illustrations are fewer than I would have thought necessary, and some of the diagrams are rather small. Since also the text is somewhat mathematical in spite of the author's claim that he has 'avoided over-rigorous arguments and mathematical complexity', the book appears rather austere. This appearance, together with its extremely high price, might well discourage many readers. This is a pity because the book contains a great deal of good material that all students should make an effort to absorb.

H. LIPSON

\author{
Department of Physics \\ University of Manchester \\ Institute of Science \& Technology \\ Manchester M60 1QD \\ England
}

\section{Crystal growth 1974. Proceedings} of the 4th International Conference. Edité parK.A.Jackson, N. Kato et J. B. Mullin. Pp. xvi + 708, Figs. 681, Tableaux 71. Amsterdam: North Holland, 1974. Prix Dfl. 300.00, U.S. $\$ 115.50$.

L'une des conférences inaugurales est intitulée: Future Needs and Opportunities in Crystal Growth - Crystal Growth Toward the Year 2000. Elle est due à R. A. Laudise.

Dans cette étude, documentée et teintée d'humour, R. A. Laudise note, par exemple, que le nombre de pages du Journal of Crystal Growth double tous les deux ans. Un tel indice, parmi d'autres, témoigne de l'intéret toujours croissant des physiciens du solide et des scientifiques de plusieurs bords pour la croissance cristalline.

Celle-ci doit fournir des cristaux de haut degré de définition et de perfection, en raison de leurs propriétés exploitables: électroniques, magnétiques, optiques, laser, IR, piézoélectriques, etc.

Le présent recueil rassemble 131 exposés (dont 74 d'auteurs japonais) répartis entre 18 sections. Ils traitent de la production améliorée de cristaux connus, ou de l'obtention d'espèces nouvelles dont on a défini par avance les propriétés spécifiques. Les rubriques les plus abondamment garnies en exposés concernent la croissance en phase vapeur (à caractère fréquemment épitaxique) et la croissance en bain fondu. En revanche, la croissance en solution à basse tempéra- 